\title{
Problem-based learning model on mathematical analytical thinking ability and science process skills
}

\author{
Syaiful1, Kamid $^{1}$, Dwi Agus Kurniawan ${ }^{1}$, Wahyu Adi Pratama ${ }^{1 *}$ \\ ${ }^{1}$ Universitas Jambi, Indonesia. \\ $\llbracket$ wahyuadipratama.wap59@gmail.com
}

Article Information

Submitted Aug 22, 2021

Revised Sep 24, 2021

Accepted Oct 16, 2021

\section{Keywords}

Problem-Based Learning Model; Analytical Thinking Skills; Science Process Skills; Mathematics.

\begin{abstract}
This research serves as a reference for teachers to implement problembased learning models on analytical thinking skills and science process skills in mathematics subjects. This research examines the differences and relationships between students' analytical thinking skills and science process skills with problem-based learning models in mathematics. The sample of this research consisted of 180 students. This research is a quantitative study with a questionnaire as the instrument. The obtained data were analyzed using the t-test and correlation test. The results showed a significant difference between analytical thinking skills and students' science process skills, especially on the indicators of Observation and Classification at SMPN 35 Batanghari and SMPN 8 Batanghari students who applied the problem-based learning model in mathematics. Furthermore, it was found that there was a relationship between analytical thinking skills and science process skills because students with analytical thinking skills possessed better science process skills in problem-based learning models in mathematics subjects.
\end{abstract}

\section{INTRODUCTION}

Improving the quality of human resources in terms of knowledge and morals is one educational Goal. Education is essential in developing attitudes, achievement, and quality to create national progresses (Hekmah et al., 2019; Mahendra, 2017; Rosyid et al., 2019). Creating qualify human resources in education can be done by guiding and facilitating the learning activities (Astalini et al., 2018; Sukendar et al; 2019., Hendri et al., 2020). Education aims to develop students' potential and skills so that they can be used in living life in society (Bellová et al., 2018; Diani et al., 2018; Elvanisi et al., 2018). The achievement of this educational potential can be obtained through good teaching.

Achieving educational goals is an obligation that must be carried out by teachers. A teacher has a very important role and influence in building students' character in schools to achieve these educational goals (Astalini et al., 2020; Sholihat et al., 2017; Widiana et al., 2018; Widiansyah, 2018 ). Generation successors who are qualified, strong, and can change the nation towards a better society can solve the problems faced by the nation (Anugrah et al., 2020; A Widiansyah, 2019; Van Den Huefel et al., 2020). Teachers can achieve educational goals using appropriate learning models.

Process skills determine students' understanding. Skills are very important for students to increase creativity and knowledge through learning activities (Vansteensel et al., 2017; Stender et al., 2018; Vartiainen \& Kumpulainen, 2020). Some of the students' skills are analytical concepts and observations (Labouta et al., 2018; Solé-Llussà et al., 2020; Stylinski et al., 2020). Student skills can be obtained by experiencing, seeking, trying, and drawing 
conclusions (Kruit et al., 2018; Solé-Llussà et al., 2019; Mutlu, 2020). Apart from students' process skills, many other things affect teacher success.

Thinking in the right pattern without being careless can be done by doing analysis in thinking. Analytical thinking is one important abilities that should be controlled by the student in the mathematics learning to help them think logically about the relationship between concept and situation (Firdaus, 2019; Ilma, 2017; Kharisma, 2018). Analytical thinking can determine the cause of an event and the arguments that support a statement (Kharisma, 2018; Yanti \& Prahmana, 2017;Hendriana, 2017). Analytical thinking can train students to learn the meaning by not only understanding relevant knowledge but can also use anything that has been studied (Yanti \& Prahmana, 2017; Nuryanti et al., 2018; Destino et al., 2019). Through analytical thinking skills, students can have a good level of understanding in learning.

The selection of the learning model used must be appropriate to the conditions. The learning model greatly influences the learning process and outcomes (Brinus et al., 2019; Cahyaningrum et al., 2019; Hanifah et al., 2019). The problem-based learning model used by teachers in learning is useful for forming students to think critically (Trisdiono et al., 2019; Ulandari et al., 2019; Zulkarnain et al., 2019). The selection of learning models requires the teachers' competence to attract the students' learning interests (Ismawati, 2017; Aprida \& Dasopang, 2017).

An understanding of important concepts and principles can be developed with a problem-based learning model. The problem-based learning model greatly influences the learning process by combining concepts (Kristanti et al., 2016; Mahasneh \& Alwan, 2018; Trishchenko, 2018). A problem-based learning model can be said as a teaching that integrates the technology and the problems of everyday life (Trianto, 2013; Rati et al., 2017; Maryati, 2018). The problem-solving approach is a learning approach that allows students to gain experience using knowledge and skills that they already possess to be applied in problemsolving (Anwar \& Asriani, 2017; Fauziyah, 2017). Therefore, the problem-based learning learning model is the right learning model.

Science plays an important role in everyday life. Mathematics is one of the basic sciences that plays an important role in science, technology, and everyday life (Siagian, 2016; N. T. Anwar, 2018). Mathematics learning can hone students' abilities to think logically, analytically, critically, and systematically (Saleh et al., 2018; Kenedi, 2019; Nurlaily et al., 2019). Solving mathematics problems requires soft skills and critical thinking skills (Hendriana et al., 2018; Ambussaidi \& Yang, 2019; Lin et al., 2020). Therefore, the development in the teaching and learning process of mathematics is necessary.

This research is in line with the research on process skills by (Vartiainen \& Kumpulainen, 2020; Stender et al., 2018; Vansteensel et al., 2017). However, their studies only measured students' skills with one variable without a learning model. This research is in line with the analytical thinking research conducted by (Badjeber et al., 2018; Ilma et al., 2017). However, the research only has one variable without using a learning model. Therefore, this research is conducted to complement the previous studies.

Based on the description, the problem-based learning model has a relationship with students' analytical thinking skills and science process skills in mathematics. Therefore, the purpose of this research was to determine the differences and the relationship between the analytical thinking and process skills in mathematics. The urgency of this research is to help 
teachers understand the differences and the relationship between problem-based learning models and students' analytical thinking skills and science process skills in mathematics.

\section{METHODS}

This research employed the associative quantitative method with a correlational research design. According to (Cohen et al., 2017), the quantitative associative method aims to determine the relationship between two or more variables. On the other hand, correlation design is a procedure in quantitative research to measure the relationship between two or more variables using statistical correlation analysis procedures (Creswell, 2016).

The research subjectS were the students of SMP 35 Batanghari and SMP 8 Batanghari selected using the purposive sampling technique. the purposive sampling technique is a sampling technique based on criteria where students ' total number is 1 to 80 students. The research samples used in this research are as follows:

Table 1. Research Sample

\begin{tabular}{cccccc}
\hline \multicolumn{3}{c}{ SMP 35 Batanghari } & \multicolumn{3}{c}{ SMP 8 Batanghari } \\
\hline \multicolumn{3}{c}{ Class } & \multicolumn{3}{c}{ Class } \\
\hline VIII A & VIII B & VIII C & VIII A & VIII B & VIII C \\
30 & 30 & 30 & 30 & 30 & 30 \\
\hline
\end{tabular}

The collection of data was done through the rating instruments that are very important for attitude (Purwanti et al., 2020). The instrument used was a questionnaire to explore the attitudes and interests. A Likert scale was used with the following criteria: Strongly Agree (VA), Agree (A), Not sure (N), Disagree (D), and Strongly Disagree (SD). The values of items are $\mathrm{SA}=5, \mathrm{~A}=4, \mathrm{~N}=3, \mathrm{D}=2$, and $\mathrm{SD}=1$.

The detail of the student's process skills questionnaire instrument is as follows :

Table 2. The Specification of Student' Science Process Skills Questionnaire

\begin{tabular}{lll}
\hline Variable & Indicator & No. Statement Items \\
\hline & Observation & $1,2,3$ \\
& Communication & $4,5,6,7$ \\
& Classification & $8,9,10,11,12$ \\
& Measure & $13,14,15$ \\
& Conclusion & $16,17,18,19$ \\
Process skills towards mathematics & Prediction & $20,21,22,23,24$ \\
& Arrange Table & $25,26,27$ \\
& Obtaining and Processing Data & $28,29,30,31$ \\
& Experimental Analysis & $32,33,34,35$ \\
& Creating a Hypothesis & $36,37,38$ \\
& Designing Experiments & $39,40,41,42,43$ \\
& Doing Experiments & $44,45,46,47$ \\
\hline Number of Statements & & 48 \\
\hline
\end{tabular}

Furthermore, the intervals in each category can be seen in Table 3. 
Table 3 . Categories skillss process toward mathematics

\begin{tabular}{lcc}
\hline \multirow{2}{*}{ Category } & \multicolumn{2}{c}{ Indicator Interval } \\
\cline { 2 - 3 } & \multicolumn{2}{c}{ Observation Classification } \\
\hline Poor & $3.0-5.25$ & $5.0 .-8.75$ \\
\hline Low & $5.26-7.50$ & $8.76-12.5$ \\
\hline High & $7.51-9.75$ & $12.6-16.25$ \\
\hline Excellent & $9.76-12.00$ & $16.26-20.0$ \\
\hline
\end{tabular}

The research data was in the form of quantitative data and the analysis used was descriptive and inferential statistical analysis. According to (Cohen et al., 2017), descriptive statistics is the description or presentation of data in a number and frequency summaries (mode, mean, median, minimum, maximum). On the other hand, the inferential statistics is an inference of mathematical procedures to use probability and information about the sample to draw conclusions about the population from which the sample might be drawn (Johnson \& Christenen, 2012). The assumption tests were carried out to see whether the data was normal, homogeneous, and linearly distributed. Then, a hypothesis test was carried out using the t-test to see the difference and the correlation between the two variables. The results of the questionnaire were processed using SPSS application software. The treatment was aimed at the problem-based learning model toward students' analytical thinking and science process skills.

In collecting the data, the researchers chose students based on the predetermined categories. Then, the researchers distributed the questionnaire. Furthermore, the questionnaire data were processed using the SPSS application. The SPSS application analyzed the descriptive statistics of mean, min, max, percentage, and students categories (Pratama \& Pramesti, 2018). THE data collection procedure of this research is contained in the following diagram :
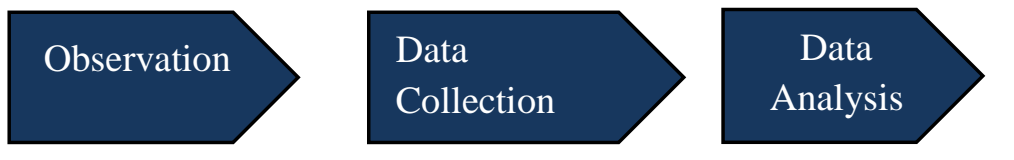

Conclusion

Figure 1. Research Procedure

\section{RESULTS AND DISCUSSION}

The description of the science process skills of SMP 35 Batanghari and SMP 8 Batanghari are as follows :

Table 4 . Description of Students' Process Skills On Classification Indicators

\begin{tabular}{|c|c|c|c|c|c|c|c|c|}
\hline Student Responses & Interval & $\mathrm{F}$ & Percentage & Category & Mean & Median & Min & Max \\
\hline \multirow{4}{*}{$\begin{array}{l}\text { SMP35 Batangh } \\
\text { ari }\end{array}$} & $5.0-8.75$ & 2 & $6.6 \%$ & Poor & \multirow{4}{*}{ 2. 32} & \multirow{4}{*}{3.00} & \multirow{4}{*}{$\begin{array}{l}2.0 \\
0\end{array}$} & \multirow{4}{*}{3.00} \\
\hline & $8.85-12.5$ & 9 & $29.7 \%$ & Low & & & & \\
\hline & $12.6-16.25$ & 19 & $62.7 \%$ & High & & & & \\
\hline & $16.35-20.0$ & 0 & $0 \%$ & Excellent & & & & \\
\hline \multirow{4}{*}{$\begin{array}{l}\text { SMP } \\
8 \text { Batanghari }\end{array}$} & $5.0-8.75$ & 3 & $9.9 \%$ & Poor & \multirow{4}{*}{2.79} & \multirow{4}{*}{3.00} & \multirow{4}{*}{1.00} & \multirow{4}{*}{4.00} \\
\hline & $8.85-12.5$ & 3 & $9.9 \%$ & Low & & & & \\
\hline & $12.6-16.25$ & 20 & $66 \%$ & High & & & & \\
\hline & $16.35-20.0$ & 4 & $13.2 \%$ & Excellent & & & & \\
\hline
\end{tabular}


Table 4 shows that students' skills towards mathematics in the classification indicator were high, with the percentage of $62.7 \%$ obtained by SMP 35 Batanghari and $66 \%$ obtained by SMP 8 Batanghari. Therefore, the SMP students of both schools had the same good response in science process skills through classification indicators.

The description of students' science process skills towards mathematics at SMP 35 Batanghari and SMP 8 Batanghari on observation indicator is as follows:

Table 5. The Description of Students' Science Process Skills on Observation Indicators

\begin{tabular}{|c|c|c|c|c|c|c|c|c|}
\hline Student Response & Interval & $\mathbf{F}$ & Percentage & Category & Mean & Median & Min & Max \\
\hline \multirow{4}{*}{$\begin{array}{l}\text { SMP } \\
35 \text { Batanghari }\end{array}$} & $3.0-5.25$ & 0 & $0 \%$ & Poor & \multirow{4}{*}{3.12} & \multirow{4}{*}{3.00} & \multirow{4}{*}{2.00} & \multirow{4}{*}{4.00} \\
\hline & $5.26-7.50$ & 6 & $19.8 \%$ & Low & & & & \\
\hline & $7.51-9.75$ & 18 & $59.4 \%$ & High & & & & \\
\hline & $9.76-12.00$ & 6 & $19.8 \%$ & Excellent & & & & \\
\hline \multirow{4}{*}{$\begin{array}{l}\text { SMP } \\
8 \text { Batanghari }\end{array}$} & $3.0-5.25$ & 1 & $3.3 \%$ & Poor & \multirow{4}{*}{2.75} & \multirow{4}{*}{3.00} & \multirow{4}{*}{1.00} & \multirow{4}{*}{3.00} \\
\hline & $5.26-7.50$ & 9 & $29.7 \%$ & Low & & & & \\
\hline & $7.51-9.75$ & 20 & $66 \%$ & High & & & & \\
\hline & $9.76-12.00$ & 0 & $0 \%$ & Excellent & & & & \\
\hline
\end{tabular}

Table 5 displays the description of students' science process skills towards mathematics in the observation indicators was in the high category with the percentage of $59.4 \%$ obtained by SMP 35 Batanghari and 66\% obtained by SMP 8 Batanghari. Therefore, both schools had the same good response in students' science process skills through observation indicators. The description of students' analytical thinking towards mathematics in SMP 35 Batanghari and SMP 8 Batanghari is as follows:

Table 6. The Description of Students' Analytical Thinking

\begin{tabular}{|c|c|c|c|c|c|c|c|c|}
\hline Student Response & Interval & $\mathrm{F}$ & Percentage & Category & Mean & Median & Min & $\operatorname{Max}$ \\
\hline \multirow{5}{*}{$\begin{array}{l}\text { SMP } \\
35 \text { Batanghari }\end{array}$} & $5.0-9.0$ & 0 & $0 \%$ & Poor & \multirow{5}{*}{3.32} & \multirow{5}{*}{4.00} & \multirow{5}{*}{3.00} & \multirow{5}{*}{5.00} \\
\hline & $10.0-13.0$ & 1 & $3.3 \%$ & Low & & & & \\
\hline & $14.0-17.0$ & 9 & $29.7 \%$ & Moderate & & & & \\
\hline & $18.0-21.0$ & 20 & $66 \%$ & High & & & & \\
\hline & $22.0-25.0$ & 0 & $0 \%$ & Excellent & & & & \\
\hline \multirow{5}{*}{$\begin{array}{l}\text { SMP } \\
8 \text { Batanghari }\end{array}$} & $5.0-9.0$ & 2 & $6.6 \%$ & Poor & \multirow{5}{*}{2.98} & \multirow{5}{*}{3.00} & \multirow{5}{*}{1.00} & \multirow{5}{*}{5.00} \\
\hline & $10.0-13.0$ & 1 & $3.3 \%$ & Low & & & & \\
\hline & $14.0-17.0$ & 8 & $26.4 \%$ & Moderate & & & & \\
\hline & $18.0-21.0$ & 12 & $39.6 \%$ & High & & & & \\
\hline & $22.0-25.0$ & 7 & $23.1 \%$ & Excellent & & & & \\
\hline
\end{tabular}

Based on Table 6, students' analytical thinking percentage obtained by SMP 35 Batanghari was $66 \%$, and the percentage obtained by SMP 8 Batanghari was $39.4 \%$. Therefore, both schools' proficiency levels were high.

The description of the students' responses toward the PBL model at SMP 35 Batanghari and SMP 8 Batanghari is as follows: 
Table 7. The Description of the Students' Responses toward PBL Model

\begin{tabular}{|c|c|c|c|c|c|c|c|c|}
\hline Student Response & Interval & $\mathrm{F}$ & Percentage & Category & Mean & Median & Min & Max \\
\hline \multirow{6}{*}{$\begin{array}{l}\text { SMP } \\
\text { 35 Batanghari }\end{array}$} & $5.0-9.0$ & 0 & $0 \%$ & Poor & \multirow{6}{*}{ 3. 12} & \multirow{6}{*}{3.00} & \multirow{6}{*}{1.00} & \multirow{6}{*}{4.00} \\
\hline & & & & & & & & \\
\hline & $10.0-13.0$ & 2 & $6.6 \%$ & Low & & & & \\
\hline & $14.0-17.0$ & 9 & $29.7 \%$ & Moderate & & & & \\
\hline & $18.0-21.0$ & 19 & $62.7 \%$ & High & & & & \\
\hline & $22.0-25.0$ & 0 & $0 \%$ & Excellent & & & & \\
\hline \multirow{5}{*}{$\begin{array}{l}\text { SMP } \\
8 \text { Batanghari }\end{array}$} & $5.0-9.0$ & 0 & $0 \%$ & Poor & \multirow{5}{*}{2.86} & \multirow{5}{*}{3.00} & \multirow{5}{*}{2.00} & \multirow{5}{*}{5.00} \\
\hline & $10.0-13.0$ & 0 & $0 \%$ & Low & & & & \\
\hline & $14.0-17.0$ & 6 & $19.8 \%$ & Moderate & & & & \\
\hline & $18.0-21.0$ & 18 & $59.4 \%$ & High & & & & \\
\hline & $22.0-25.0$ & 6 & $19.8 \%$ & Excellent & & & & \\
\hline
\end{tabular}

Based on Table 7, students' responses toward the PBL model were high, with a percentage of $62.7 \%$ obtained by SMP 35 Batanghari and 59.4\% obtained by SMP 8 Batanghari. It can be concluded that both schools provided good responses toward the PBL model in mathematics.

\section{Assumption Tests}

\section{Normality Test}

The normality results on science process skills, analytical thinking, and the PBL model can be seen in Table 8 .

Table 8. Test Normality Test Results

\begin{tabular}{|c|c|c|c|c|c|c|c|}
\hline \multicolumn{8}{|l|}{ Normality Test } \\
\hline & \multirow{2}{*}{ Schools } & \multicolumn{3}{|c|}{ Kolmogorov-Smirnov } & \multicolumn{3}{|c|}{ Shapiro-Wilk } \\
\hline & & Statistics & $\mathrm{df}$ & Sig. & Statistics & $\mathrm{df}$ & Sig. \\
\hline & SMP 35 Batanghari & .053 & 90 & $.200^{*}$ & 944 & 90 & .096 \\
\hline \multirow[t]{2}{*}{ Science process skills } & SMP 8 Batanghari & .051 & 90 & $.200^{*}$ & 975 & 90 & .575 \\
\hline & SMP 35 Batanghari & .061 & 90 & $.200 *$ & 976 & 90 & 621 \\
\hline \multirow[t]{2}{*}{ Analytical thinking } & SMP 8 Batanghari & .054 & 90 & $.200 *$ & .953 & 90 & .131 \\
\hline & SMP 35 Batanghari & .069 & 90 & $.200^{*}$ & 979 & 90 & .722 \\
\hline PBL model & SMP 9 Batanghari & 055 & 90 & $.200 *$ & 963 & 90 & 270 \\
\hline
\end{tabular}

Based on table 8, it was found that the results of the normality test were normal. The obtained results of the Kolmogorov-Smirnov test were higher than 0.05 .

Homogeneity Test

The homogeneity test results on science process skills, analytical thinking, and PBL model at SMP 35 Batanghari and SMP 8 Batanghari can be seen in Table 9.

Table 9. The Results of the Homogeneity Test

\begin{tabular}{llllll}
\hline Test of Homogeneity of Variances & & & & \\
\hline & & Levene & & & \\
& & Statistics & df1 & df2 & Sig. \\
\hline Skills process * Analytical & Based on Mean & 2,658 & 1 & 720 & .091 \\
thinking* PBL model & Based on Median & 2,676 & 1 & 720 & .092 \\
& Based on Median and with adjusted df 2,676 & 1 & 717,263 & .092 \\
& Based on trimmed mean & 2,662 & 1 & 720 & .093 \\
\hline
\end{tabular}


Based on table 9, it can be concluded that data were homogeneous with the obtained results higher than 0.05 .

\section{Linearity Test}

The results of the linearity test can be seen in the table below :

Table 10. The Results of the Linearity Test

\begin{tabular}{|c|c|c|c|c|c|c|c|}
\hline \multicolumn{3}{|l|}{ ANOVA Table } & \multirow{2}{*}{\multicolumn{2}{|c|}{$\begin{array}{l}\text { Sum of } \\
\text { Squares } \mathrm{df}\end{array}$}} & \multirow[b]{2}{*}{ Mean } & \multirow[b]{2}{*}{$\mathrm{F}$} & \multirow[b]{2}{*}{ Sig. } \\
\hline & & & & & & & \\
\hline Analytical thinking *Science & Between & (Combined) & 2645.169 & 48 & 94,470 & 2.039 & .017 \\
\hline \multirow[t]{4}{*}{ process skills * PBL model } & Groups & linearity & 2185,264 & 1 & 2185,264 & 47.168 & .000 \\
\hline & & $\begin{array}{l}\text { Deviation } \\
\text { from } \\
\text { Linearity }\end{array}$ & 459,906 & 47 & 17,034 & .368 & .996 \\
\hline & Within $\mathrm{C}$ & troups & 1992.150 & 243 & 46,329 & & \\
\hline & Total & & 4637,319 & 539 & & & \\
\hline
\end{tabular}

Table 10 shows a linear relationship between science processes skills and analytical thinking using the PBL model at SMP 35 Batanghari and SMP 8 Batanghari. The results of the linearity test were higher than 0.05 .

\section{Hypothesis Testing}

The hypothesis test was performed using the t-test and correlation test. The t-test aims to determine the difference in the average sample taken, while the correlation test shows whether there is a relationship between the two variables. The t-test result can be seen in the following table:

Table 11. The Result of T-Test

\begin{tabular}{|c|c|c|c|c|c|c|}
\hline \multicolumn{7}{|l|}{ Independent Samples Test } \\
\hline \multirow{4}{*}{$\begin{array}{l}\text { Analytical thinking at SMP } \\
35 \text { Batanghari and SMP } \\
8 \text { Batanghari }\end{array}$} & \multirow{4}{*}{$\begin{array}{l}\text { Equal variances assumed } \\
\text { Equal variances not assumed }\end{array}$} & \multicolumn{5}{|c|}{ Levene's Test for Equality of Variances } \\
\hline & & $\mathrm{F}$ & Sig. & $\mathrm{t}$ & df & $\begin{array}{l}\text { Sig. (2- } \\
\text { tailed) }\end{array}$ \\
\hline & & .162 & .541 & 3.997 & 180 & .000 \\
\hline & & & & 4.012 & 122.881 & .000 \\
\hline \multirow{4}{*}{$\begin{array}{l}\text { Science process skills at } \\
\text { SMP } 35 \text { Batanghari and } \\
\text { SMP } 8 \text { Batanghari }\end{array}$} & & $\mathrm{F}$ & Sig. & $\mathrm{t}$ & df & $\begin{array}{l}\text { Sig. (2- } \\
\text { tailed) }\end{array}$ \\
\hline & Equal variances assumed & .132 & .739 & 2,419 & 180 & .000 \\
\hline & Equal variances not assumed & & & 2,494 & 132.891 & .000 \\
\hline & & $\mathrm{F}$ & Sig. & $\mathrm{t}$ & $\mathrm{df}$ & $\begin{array}{l}\text { Sig. (2- } \\
\text { tailed) }\end{array}$ \\
\hline \multirow{2}{*}{$\begin{array}{l}\text { PBL model at SMP } \\
35 \text { Batanghari and SMP } \\
8 \text { Batanghari }\end{array}$} & Equal variances assumed & .187 & .721 & 2,638 & 180 & .000 \\
\hline & Equal variances not assumed & & & 2,612 & 121.771 & .000 \\
\hline
\end{tabular}


Table 11 shows a difference between science process skills and analytical thinking using the PBL model at SMP 35 Batanghari and SMP 8 Batanghari proven by the value sig ( 2-tailed) 0.000, which is lower than 0.05 .

\section{Correlation Test}

The result of the correlation test is displayed in the table below.

Table 12. The Result of Correlation Test

\begin{tabular}{lll}
\hline Correlations & & \\
\hline & & RESULT \\
\hline & Pearson Correlation & $.690^{* *}$ \\
Analytical thinking at SMP 35 Batanghari & Sig. (2-tailed) & .033 \\
and SMP 8 Batanghari & $\mathrm{N}$ & 180 \\
& Pearson Correlation & $.884^{* *}$ \\
Science process Skills at SMP 35 Batanghari & Sig. (2-tailed) & .000 \\
and SMP 8 Batanghari & $\mathrm{N}$ & 180 \\
& Pearson Correlation & $.729^{* *}$ \\
PBL model SMP 35 Batanghari and & Sig. (2-tailed) & .023 \\
SMP 8 Batanghari & $\mathrm{N}$ & 180 \\
\hline
\end{tabular}

Table 12 shows a relationship between science process skills and analytical thinking using the PBL model at SMP 35 Batanghari and SMP 8 Batanghari proven by the Sig. Value of (2-failed) 0.023 which is higher than 0.05 .

Descriptive statistics are types of statistics that process statistical analysis by classifying the processed data. In this research, the researchers examined the science process skills and analytical thinking using the PBL model at SMP 35 Batanghari and SMP 8 Batanghari. The classification indicators were in the high category with a percentage of $62.7 \%$ obtained by SMP 35 Batanghari, and SMP 8 Batanghari obtained a percentage of $66 \%$. Therefore, both schools had good responses. Furthermore, the observation indicators were in the high category with $59.4 \%$ obtained by SMP 35 Batanghari and a percentage of $66 \%$ obtained by SMP 8 Batanghari. Therefore, both schools had good responses.

The students' analytical thinking skills were high, with a percentage of $66 \%$ obtained by SMP 35 Batanghari and $39.4 \%$ obtained by SMP 8 Batanghari. It can be concluded that both schools' proficiency levels were high. The students' PBL model was high, with a percentage of $62.7 \%$ obtained by SMP 35 Batanghari, and SMP 8 Batanghari obtained $59.4 \%$. Therefore, both schools had good responses.

The normality test of science process skills and analytical thinking using the PBL model in mathematics at SMP 35 Batanghari and SMP 8 Batanghari was normally distributed. The results of the Kolmogorov-Smirnov test were higher than 0.05 . The homogeneity test results on science process skills and analytical thinking using the PBL model at SMP 35 Batanghari and SMP 8 Batanghari were homogeneous with a significant value higher than 0.05 . The linearity test on science process skills and analytical thinking using the PBL model showed a linear relationship proven by the Sig value that was higher than 0.05. Hypothesis testing can be carried out since the data met the requirements, namely normally distributed, homogeneous, and linear. 
The t-test on science process skills and analytical thinking using the PBL model at SMP 35 Batanghari and SMP 8 Batanghari showed a difference proven by the Sig. Value of ( 2tailed) 0.000 which is lower than 0.05 . The correlation test of science process skills and analytical thinking using the PBL model showed a relationship proven by the Sig. Value of (2-failed) 0.023 which is higher than 0.05 .

This research is in line with the research on process skills (Vartiainen \& Kumpulainen, 2020; Stender et al., 2018; Vansteensel et al., 2017). However, their research only measured students' skills with one variable and without using a learning model. This research is in line with the analytical thinking research conducted by (Ilma et al., 2017). However, their research only has one variable and without using a learning model. Therefore, this research was conducted to complement the previous research.

In this research, researchers examined the problem-based learning model with variables of analytical thinking ability and science process skills of junior high school students in learning mathematics. It can be seen that the problem-based learning model used has a relationship with students' science process skills and analytical thinking in mathematics. The science process skills and good analytical thinking can develop students' knowledge and skills regarding mathematics lessons. The science process skills and analytical thinking with the PBL model can evaluate problems related to mathematics subjects. Therefore, good science process skills and analytical thinking are formed to produce good impacts.

The urgency of this research is to help educators understand the differences and relationships between students' analytical thinking skills and science process skills in mathematics subjects using a problem-based learning model. The drawback of this research is that it only measures the variables of analytical thinking and science process skills in the PBL learning model and has not been tested with other variables such as self-efficacy, attitudes, interests, motivation, and others. Therefore, it is possible to read or do further research with different variables.

\section{CONCLUSIONS}

Based on the analysis and research results, it can be concluded that based on the t-test, there was a significant difference between the analytical thinking skills and the science process skills of students at SMP Negeri 35 Batanghari and SMP Negeri 8 Batanghari in mathematics, especially on the indicators of Observation and Classification. Furthermore, in the correlation test, it was found that there was a relationship between analytical thinking skills and science process skills because students who have analytical thinking skills will have better science process skills in problem-based learning models. It is hoped that further research can be carried out using different variables, populations, and learning models.

\section{AUTHOR CONTRIBUTIONS STATEMENT}

This article was conceptualized and original written by ADK. ES participated in the methodology, validation and data curation. For review and editing carried out by all authors.

\section{REFERENCES}

Ambussaidi, I., \& Yang, Y.-F. (2019). The impact of mathematics teacher quality on student 
achievement in oman and Taiwan. International Journal of Education and Learning, $1(2), 50-62$.

Anugrah, D., Murwitaningsih, S., Sofyan, D. A., \& Susilo, S. (2020). Model pembelajaran kreatif treffinger terhadap kemampuan memecahkan masalah pada materi ekosistem dan perubahan lingkungan. JPBIO (Jurnal Pendidikan Biologi), 5(1), 73-79.

Anwar, B., \& Asriani. (2017). Penerapan pembelajaran problem solving untuk meningkatkan aktivitas dan hasil belajar matematika pada materi SPLDV. Jurnal Pendidikan Matematika, 4(2), 224-239.

Anwar, N. T. (2018). Peran kemampuan literasi matematis pada pembelajaran matematika abad-21. Prosiding Seminar Nasional Matematika, 1, 364-370.

Aprida, P., \& Dasopang, D.M. (2017). Belajar dan pembelajaran. fitrah: Jurnal kajian ilmuilmu keislaman. Jurnal Kajian Ilmu-Ilmu Keislaman, 3(2), 333-352.

Astalini, A., Darmaji, D., Kurniawan, D. A., Anggraini, L., \& Perdana, R. (2020). Eassessment on student's self-concept for physics learning. Jurnal Ilmu Pendidikan, 25(2), 73-81.

Astalini, A., Kurniawan, D. A., \& Sumaryanti, S. (2018). Sikap siswa terhadap pelajaran fisika di sman kabupaten batanghari. JIPF (Jurnal Ilmu Pendidikan Fisika), 3(2), 59-64.

Brinus, K. S. W., Makur, A. P., \& Nendi, F. (2019). Pengaruh model pembelajaran kontekstual terhadap pemahaman konsep matematika siswa SMP. Mosharafa: Jurnal Pendidikan Matematika, 8(2), 261-272.

Cahyaningrum, A. D., AD, Y., \& Asyhari, A. (2019). Pengaruh model pembelajaran quantum teaching tipe tandur terhadap hasil belajar. Indonesian Journal of Science and Mathematics Education, 2(3), 372-379.

Cohen, L., Lawrence, M., \& Morrison, K. (2017). Research methods in education. Eighth Edition. In Research Methods in Education.

Creswell, J. W. (2016). Research design (pendekatan metode kualitatif, kuantitatif, dan campuran). In Terjemahan Bahasa Indonesia.

Destino, M. D., Bharata, H., \& Caswita, C. (2019). Pengembangan bahan ajar transformasi geometri berorientasi pada kemampuan bepikir kritis peserta didik. Kreano, Jurnal Matematika Kreatif-Inovatif, 10(1), 57-67.

Diani, R., Hartati, N. S., \& Email, C. A. (2018). Flipbook berbasis literasi Islam: Pengembangan media pembelajaran fisika dengan 3D pageflip professional flipbook based on islamic literacy: The development of physics learning media using 3D pageflip professional. Jurnal Inovasi Pendidikan IPA, 4(2), 234-244.

Elvanisi, A., Hidayat, S., \& Fadillah, E. N. (2018). Analisis keterampilan proses sains siswa sekolah menengah atas skills analysis of science process of high school students. Jurnal Inovasi Pendidikan IPA, 4(20), 245-252. 
Fauziyah, L. (2017). Model problem-based learning dengan pendekatan open-ended untuk meningkatkan kemampuan pemecahan masalah siswa. Unnes Journal of Mathematics Education Research, 6(1), 59-67.

Hanifah, H., Supriadi, N., \& Widyastuti, R. (2019). Pengaruh model pembelajaran e-learning berbantuan media pembelajaran edmodo terhadap kemampuan pemecahan masalah matematis peserta didik. NUMERICAL: Jurnal Matematika Dan Pendidikan Matematika, 31-42.

Hekmah, N., Wilujeng, I., \& Suryadarma, I. G. P. (2019). Web-lembar kerja siswa IPA terintegrasi lingkungan untuk meningkatkan literasi lingkungan siswa. Jurnal Inovasi Pendidikan IPA, 5(2), 129-138.

Hendri, M., Pramudya, L., \& Pratiwi, N. I. S. (2020). Analisis hubungan karakter semangat kebangsaan terhadap hasil belajar siswa. Jurnal Pembangunan pendidikan: Fondasi dan Aplikasi, 7(1), 1-8.

Hendriana, H. (2012). Pembelajaran matematika humanis dengan metaphorical thinking untuk meningkatkan kepercayaan diri siswa. Infinity Journal, 1(1), 90.

Hendriana, H., Johanto, T., \& Sumarmo, U. (2018). The role of problem-based learning to improve students' mathematical problem-solving ability and self confidence. Journal on Mathematics Education, 9(2), 291-299.

Ikhsan, M., Munzir, S., \& Fitria, L. (2017). Kemampuan berpikir kritis dan metakognisi siswa dalam menyelesaikan masalah matematika melalui pendekatan problem solving. AKSIOMA: Jurnal Program Studi Pendidikan Matematika, 6(2), 234-235.

Ilma, R., Hamdani, A. S., \& Lailiyah, S. (2017). Profil berpikir analitis masalah aljabar siswa ditinjau dari gaya kognitif visualizer dan verbalizer. Jurnal Review Pembelajaran Matematika, 2(1), 1-14.

Ismawati, R. (2017). Strategi react dalam pembelajaran kimia SMA. Indonesian Journal of Science and Education, 1(1), 1-7.

Johnson, R. B., \& Christenen, L. (2012). Educational research: Quantitative, qualitative, and mixed methods approaches. SAGE Publications.

Kenedi. (2019). Koneksi matematika siswa SD untuk memecahkan masalah matematika. Journal on Mathematics Education, 10(1), 69-79.

Kharisma, E. N. (2018). Analisis kemampuan berpikir kritis matematis siswa SMK pada materi barisan dan deret. Jurnal Review Pembelajaran Matematika, 3(1), 62-75.

Kristanti, Y., Subiki, S., \& Handayani, R. (2016). Model pembelajaran berbasis proyek (problem based learning model) pada pembelajaran fisika di SMA. Jurnal Pembelajaran Fisika, 5(2), 122-128.

Kruit, P. M., Oostdam, R. J., van den Berg, E., \& Schuitema, J. A. (2018). Assessing students' ability in performing scientific inquiry: Instruments for measuring science 
skills in primary education. Research in Science \& Technological Education, 36(4), 413-439.

Labouta, H. I., Kenny, N. A., Li, R., Anikovskiy, M., Reid, L., \& Cramb, D. T. (2018). Learning science by doing science: An authentic science process-learning model in postsecondary education. International Journal of Science Education, 40(12), 14761492.

Lin, S., Zhou, Y., \& Wijaya, T. T. (2020). Using hawgent dynamic mathematics software in teaching arithmetic operation. International Journal of Education and Learning, 2(1), $25-31$.

Mahasneh, A. M., \& Alwan, A. F. (2018). The effect of problem-based learning on student teacher self-efficacy and achievement. International Journal of Instruction, 11(3), 511524.

Mahendra, I. W. E. (2017). Problem based learning bermuatan etnomatematika dalam pembelajar matematika. JPI (Jurnal Pendidikan Indonesia), 6(1), 106-114.

Maryati, I. (2018). Penerapan model pembelajaran berbasis proyek dalam materi statistika kelas VIII sekolah menengah pertama. Mosharafa: Jurnal Pendidikan Matematika, 7(3), 467-476.

Mutlu, A. (2020). Evaluation of students' scientific process skills through reflective worksheets in the inquiry-based learning environments. Reflective Practice, 21(2), 271286.

Nurlaily, V. A., Soegiyanto, H., \& Usodo, B. (2019). Elementary school teacher's obstacles in the implementation of problem-based learning model in mathematics learning. Journal on Mathematics Education, 10(2), 229-238.

Nuryanti, L., Zubaidah, S., \& Diantoro, M. (2018). Analisis kemampuan berpikir kritis siswa SMP. Jurnal Pendidikan: Teori, Penelitian, dan Pengembangan, 3(2), 155-158.

Pratama, R. R., \& Pramesti, R. A. (2018). The importance of stim-hots and critical thinking skill in disruption era. In Social, Humanities, and Educational Studies (SHEs): Conference Series, 1(1), 670-675.

Purwanti, E., Palupi, R. Z. P., Galuh, A., \& Rianingsih, D. (2020). Pengembangan instrumen penilaian keterampilan abad 21. Kota Tua.

Rati, N. W., Kusmaryatni, N., \& Rediani, N. (2017). Model pembelajaran berbasis proyek, kreativitas dan hasil belajar mahasiswa. JPI (Jurnal Pendidikan Indonesia), 6(1), 60-71.

Rosyid, M. Z., Mansyur, M., IP, S., Abdullah, A. R., \& Pd, S. (2019). Prestasi belajar. Literasi Nusantara.

Saleh, M., Charitas, R., Prahmana, I., \& Isa, M. (2018). Improving the reasoning ability of elementary school student through the indonesian realistic. Journal on Mathematics Education, 9(1), 41-54. 
Sholihat, F. N., Samsudin, A., \& Nugraha, M. G. (2017). Identifikasi miskonsepsi dan penyebab miskonsepsi siswa menggunakan four-tier diagnostic test pada sub-materi fluida dinamik: Azas kontinuitas. Jurnal Penelitian \& Pengembangan Pendidikan Fisika, 3(2), 175-180.

Siagian, M. D. (2016). Model pembelajaran kooperatif tipe circ dengan pendekatan konstruktivisme untuk meningkatkan kemampuan koneksi matematik. Unnes Journal of Mathematics Education Research, 1(2), 58-67.

Solé-Llussà, A., Aguilar, D., \& Ibáñez, M. (2020). Video-worked examples to support the development of elementary students' science process skills: A case study in an inquiry activity on electrical circuits. Research in Science and Technological Education, 1-21.

Solé-Llussà, Anna, Aguilar, D., \& Ibáñez, M. (2019). Video worked examples to promote elementary students' science process skills: A fruit decomposition inquiry activity. Journal of Biological Education, 1-12.

Stender, A., Schwichow, M., Zimmerman, C., \& Härtig, H. (2018). Making inquiry-based science learning visible: The influence of CVS and cognitive skills on content knowledge learning in guided inquiry. International Journal of Science Education, 40(15), 1812-1831.

Stylinski, C. D., Peterman, K., Phillips, T., Linhart, J., \& Becker-Klein, R. (2020). Assessing science inquiry skills of citizen science volunteers: A snapshot of the field. International Journal of Science Education, Part B, 10(1), 77-92.

Trianto. (2013). Model pembelajaran terpadu: Konsep, strategi dan implementasinya dalam kurikulum tingkat satuan pendidikan (KTSP). Jakarta, PT Bumi Aksara.

Trisdiono, H., Siswandari, S., Suryani, N., \& Joyoatmojo, S. (2019). Development of multidisiplin integrated problem-based learning model to improve critical thinking and cooperation skills. JPI (Jurnal Pendidikan Indonesia), 8(1), 9-20.

Trishchenko, D. A. (2018). Experience of problem-based learning: An attempt at objective analysis of results and problems. The Education and science journal, 20(4), 132-152.

Ulandari, N., Putri, R., Ningsih, F., \& Putra, A. (2019). Efektivitas model pembelajaran inquiry terhadap kemampuan berpikir kreatif siswa pada materi teorema pythagoras. Jurnal Cendekia : Jurnal Pendidikan Matematika, 3(2), 227-237.

Van den Heuvel, R. J. F., Lexis, M. A. S., \& de Witte, L. P. (2020). ZORA robot based interventions to achieve therapeutic and educational goals in children with severe physical disabilities. International Journal of Social Robotics, 12(2), 493-504.

Vansteensel, M. J., Kristo, G., Aarnoutse, E. J., \& Ramsey, N. F. (2017). The brain-computer interface researcher's questionnaire: From research to application. Brain-Computer Interfaces, 4(4), 236-247. 
Vartiainen, J., \& Kumpulainen, K. (2020). Playing with science: Manifestation of scientific play in early science inquiry. European Early Childhood Education Research Journal, 28(4), 490-503.

Widiansyah, A. (2019). Pengendalian mutu: Implementasi manajemen sumber daya manusia, optimalisasi fungsi pengendalian dalam dunia pendidikan. Cakrawala-Jurnal Humaniora, 19(1), 21-26.

Widiansyah, A. (2018). Peranan sumber daya pendidikan sebagai faktor penentu dalam manajemen sistem pendidikan. Manajemen Sistem Pendidikan. Cakrawala-Jurnal Humaniora, 18(2), 229-234..

Wuryandani, W., Fathurrohman, F., \& Ambarwati, U. (2016). Implementasi pendidikan karakter kemandirian di muhammadiyah boarding school. Jurnal Cakrawala Pendidikan, 15(2), 208-216.

Yamashita, S., Yeo, J., Nakanishi, K., Kojima, K., Igarashi, R., Terasawa, A., Chang, J., Toh, J., Pang, A., Ashardianto, S., \& Nomura, J. (2019). Development and evaluation of global positioning system science lesson based on science, technology, engineering, and mathematics model in Singapore. Science Education International, 30(3), 194-199.

Yanti, O. F., \& Prahmana, R. C. I. (2017). Model problem-based learning, guided inquiry, dan kemampuan berpikir kritis matematis. Jurnal Review Pembelajaran Matematika, 2(2), $120-130$.

Zulkarnain, Z., Andayani, Y., \& Hadisaputra, S. (2019). Peningkatan keterampilan berpikir kritis peserta didik pada pembelajaran kimia menggunakan model pembelajaran preparing dong concluding. Jurnal Pijar Mipa, 14(2), 96-100. 